\title{
Models Comparative Study for Estimating Crop Water Requirement and Irrigation Scheduling of Maize in Metekel Zone, Benishangul Gumuz Regional State, Ethiopia
}

\author{
Ashebir Haile Tefera ${ }^{1,}$, Demeke Tamene Mitiku \\ ${ }^{1}$ Ethiopian Institute of Agricultural Research, Debre Zeit Agricultural Research Centre, Debre Zeit, Ethiopia \\ ${ }^{2}$ Ethiopian Institute of Agricultural Research, Pawe Agricultural Research Centre, Pawe, Ethiopia \\ Email address: \\ ashu_haile@yahoo.com (A. H. Tefera), haileashebir@gmail.com (A. H. Tefera),demeketamene8@gmail.com (D. T. Mitiku) \\ ${ }^{*}$ Corresponding author
}

To cite this article:

Ashebir Haile Tefera, Demeke Tamene Mitiku. Models Comparative Study for Estimating Crop Water Requirement and Irrigation Scheduling of Maize in Metekel Zone, Benishangul Gumuz Regional State, Ethiopia. International Journal of Agricultural Economics. Vol. 6, No. 2, 2021, pp. 59-70. doi: 10.11648/j.ijae.20210602.11

Received: December 13, 2020; Accepted: January 4, 2021; Published: January 15, 2021

\begin{abstract}
This study was aimed to compare estimation methods of crop water requirement and irrigation scheduling for major crops using different models and compare the significance of models for adoption in different situations of the Metekel zone. Crop water requirement and irrigation scheduling of maize in selected districts of Metekel zone were estimated using CropWat model based on soil, crop and meteorological data, and AquaCrop based on soil, crop and meteorological data including $\mathrm{Co}_{2}$, groundwater, field management, and fertility status. Model performance was evaluated using Normalized Root mean square errors (NRMSE), model by Nash-Sutcliffe efficiency (NSE), Prediction error (Pe), and Model efficiency (MF). It is observed that the maximum reference evapotranspiration in the study area was found to be $7.1 \mathrm{~mm} / \mathrm{day}$ in Guba and the minimum reference evapotranspiration was $2.9 \mathrm{~mm} /$ day in Bullen district. In all cases, the maximum ETo in all districts was fund to in March and the lowest in August. The maximum ETc of maize was found to be $702.4 \mathrm{~mm}$ in Guba district and the minimum ETc was found to be $572.6 \mathrm{~mm}$ in Bullen district using CropWat but the effective rainfall (Pe) for maize was determined as $185 \mathrm{~mm}$ respectively in Wembera district. However, using the AquaCrop model the maximum ETc of $565 \mathrm{~mm}$ was recorded in Guba but $425 \mathrm{~mm}$ was recorded as a minimum in the Wembera district for irrigated maize in the study area. The study revealed that the irrigation scheduling with a fixed interval criterion for maize 10 days with 12 irrigation events has been determined. Moreover, furrow irrigation with $60 \%$ irrigation application efficiency was adjusted during irrigation water applications for all districts. The performance of the irrigation schedule and crop response was evaluated by the analysis results in the simulation using different models. It has been observed that there were a strong relationship and a significant relation between the simulated and observed values for validation. Hence, Normalized Root mean square errors (NRMSE), model by Nash-Sutcliffe efficiency (NSE), Prediction error (Pe), and Model efficiency (MF) showed that the AquaCrop model well simulated in all parameters considered. AquaCrop model is the most suitable soil-water-crop-environment management model, so future studies should suggest a focus on addressing deficit irrigation strategy with different field management conditions to improve agricultural water productivity under irrigated agriculture for the study area for major crops.
\end{abstract}

Keywords: Depilation, Irrigation Events, AquaCrop, Fixed Interval and Deficit Irrigation

\section{Introduction}

Irrigation implies the application of suitable water to crops in the right amount at the right time [11] Irrigation scheduling is important for developing best management practices for irrigated areas [5]. There is considerable scope for improving water use efficiency of these crops by proper irrigation scheduling governed by crop evapotranspiration $[12,5]$ have suggested that the crop coefficient values need to be derived empirically for each crop based on lysimetric data and local climatic conditions.

Maize (Zea mays L.) is the world's third most important 
cereal crop after wheat and rice are grown primarily for grain and secondly for fodder [31]. Seasonal maize water uses various according to the evaporative demand of the atmosphere, and hence according to climate, time of the season when the crop is grown, the life cycle length of the crop, and water availability [17]. The typical seasonal ET of a cultivar of medium-season length grown in a temperate climate at the latitude of $35^{\circ}$ to $40^{\circ}$ being around $650 \mathrm{~mm}$ [33].

The demand for water has been the main limiting factor for crop production in much of the world where rainfall is not ample. The ever increase in the human population is stimulating the rise in demand for a large quantity of crop yield [26]. Sustaining this population will require increased production of all crops. There is also a limited amount of arable land and the resources to produce food are becoming scarcer. As population rises, less land will be devoted to agriculture, meaning increased production will have to come from increased yields [28]. In Metekel zone, almost all farmers are poor in water resource management and lack of experience and knowledge about how much and when to irrigate efficiently for irrigation water saving-strategies to tackle the shortage of rainfall and dry spell [10]. This results in waterlogging, soil erosion, accumulation of salt, and loss of irrigation water resources. Therefore, there is a need to improve the water use efficiency to obtain more crop production per drop of water with declining irrigation resources and the uncertainty in the temporal and spatial distribution of rainfall. Among many, one of the mechanisms or strategies to improve crop productivity per unit of water under full irrigation is the employment of the aid of models to fill the gaps during dry spells [13]. It has been reported by different scholars that the crop water requirement and irrigation scheduling determined using CropWat. However, the comparative study using the CropWat and AquaCrop model for the determination of crop water requirement and irrigation scheduling of major crops in the study area hasn't been done yet to the best of my knowledge.

The model simulation is a simplification of the field processes, but it attempts to account for the most important factors that influence the model performance. Determination of crop water requirement and irrigation scheduling will provide information that increases water use efficiency and increase the productivity of maize crops in the study area. However, the performance of models varies from one another based on various factors. Therefore, evaluation and identification of the best model for maximizing the efficiency of water use in crop production are unquestionable. Consequently, sustainable and effective utilization of scarce water resources may promote and contribute to poverty alleviation in the area and enhance food security through maximizing crop production of the farmers. The objective of this study was to compare and evaluate ETo, crop water requirement, and irrigation scheduling for maize using CropWat and AquCrop to improve water productivity for sustainable agricultural production under irrigated agriculture.

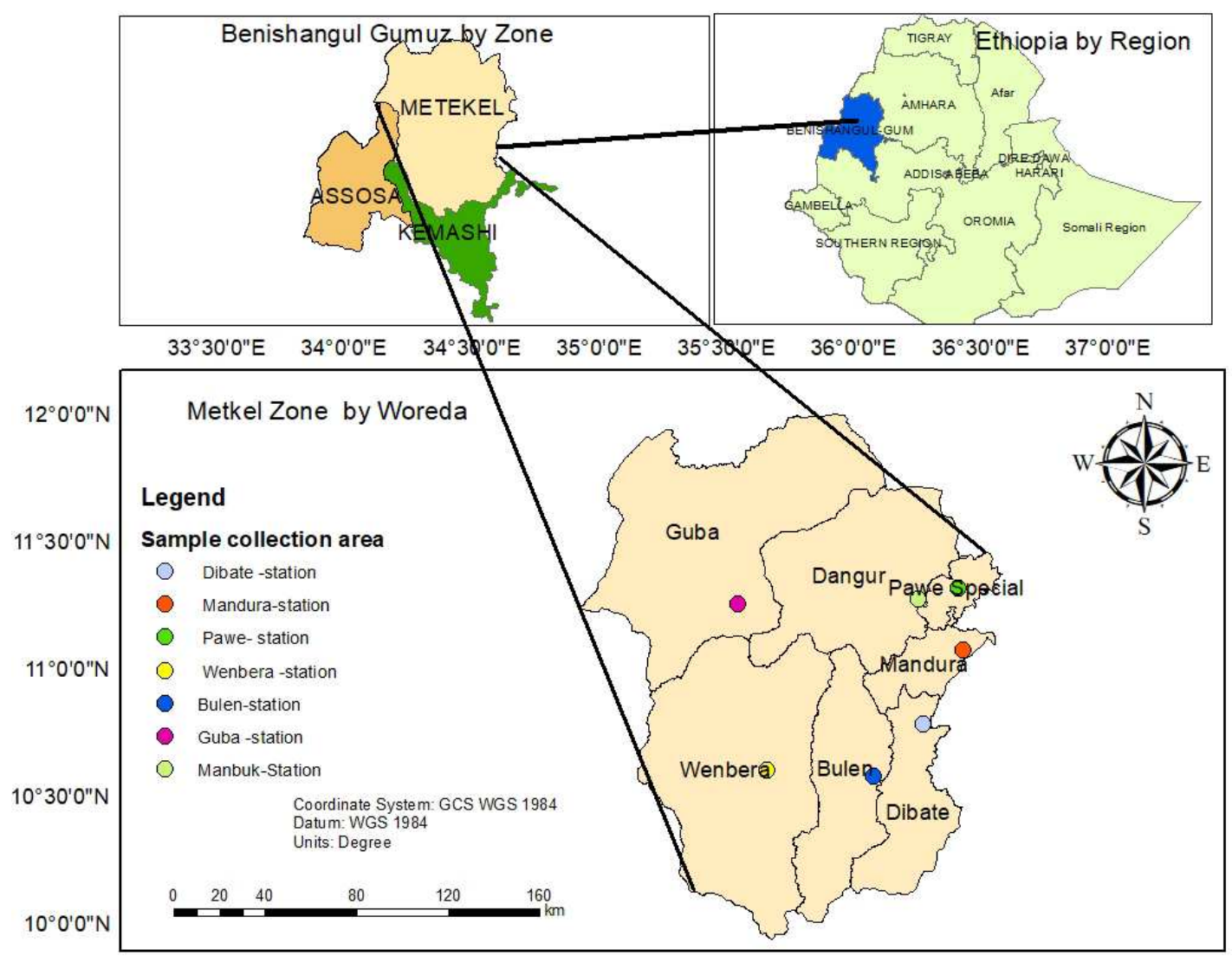

Figure 1. Location of study area. 


\section{Materials and Methods}

\subsection{Description of the Study Area}

The study was conducted in Metekel zone of Benishangul Gumuz Regional State, North-West of Ethiopia. It is the largest zone of the region covering an area of 3,387,817 hectares consisting of seven 7 districts: Wombera, Bullen, Manbuk, Dibate, Mandura, Guba, and Pawe Woreda. The topography of the zone presents undulating hills slightly sloping down to low land Plateaus having varying altitudes from 600- 2800 m.a.s.l. and the annual rainfall of the area is $900-1580 \mathrm{~mm}$. About $80 \%$ of the zone is characterized by having a sub-humid and humid tropical climate [32]. Its diverse agro-ecology provides the potential for the cultivation of different crops. Farmers practice a mixed crop-livestock production system. Cereals (maize, sorghum and finger millet) and oilseeds (soybean, sesame, and groundnut) are the most important food grains mainly cultivated in the zone [1]. According to the Ministry of Agriculture (MoA) and Agricultural Transformation Agency, the surrounding of Metekel Zone has a wide climatic range within hot to warm moist lowlands and hot to warm -subhumid lowlands agro-ecological zones [29].

The annual minimum and maximum temperature of the study area is $20^{\circ} \mathrm{C}$ and $35^{\circ} \mathrm{C}$ respectively. The soil type of the study area is characterized by heavy clay soil with initially available soil moisture depletion level range 111-129 (mm/meter depth) and total available soil moisture level range 222-259 (mm/meter depth) varying with soil depth. a mean infiltration rate is $70 \mathrm{~mm} /$ day and the bulk density is varying from $1.12-1.31 \mathrm{gm} / \mathrm{cm} 3$ across the depth of 1.2 meter [6] Agricultural activities in the study area dominated by mixed crop-livestock production, which accounts $96.2 \%$ of the farmers and the rest $3.8 \%$, were involved only in livestock production [32].

\subsection{Crop Water Requirement}

\subsubsection{Crop and Irrigation Water Requirements Using CropWat Model}

CropWat 8.0 computed crop water requirement by feeding the computed monthly ETo values together with rainfall, crop type including cropping calendar together with the required soil characteristics of maize. The Kc for every growth stage was adapted from [6] and then, ETc was calculated by equation (1). The irrigation requirement was calculated using the equation (2).

$$
\begin{aligned}
\mathrm{ETc} & =\mathrm{ETo} * \mathrm{kc} \\
\mathrm{NIR} & =\mathrm{ETc}-\mathrm{Pe}
\end{aligned}
$$

Where, $\mathrm{ETc}=\mathrm{crop}$ evapotranspiration $(\mathrm{mm}), \mathrm{ETo}=$ reference evapotranspiration $(\mathrm{mm}), \mathrm{Kc}=\mathrm{crop}$ factor, $\mathrm{NIR}=$ net irrigation water requirement $(\mathrm{mm}), \mathrm{ETc}=\mathrm{crop}$ water requirement $(\mathrm{crop}$ evapotranspiration) $(\mathrm{mm}), \mathrm{Pe}=$ effective rainfall $(\mathrm{mm})$.

The amount of water applied during an irrigation event (gross irrigation) is equal to the net irrigation required between irrigation and that needed for efficiencies in the irrigation system. In this study, water was assumed to apply with precise measurements. As a result, there was no run-off and the only loss would be deep percolation and evaporation which are expected to be not much in a deficit irrigation practice. Therefore, a higher value of application efficiency $(60 \%)$ was adopted.

$$
\mathrm{GIR}=\mathrm{NIR} / \mathrm{Ea}
$$

Where, GIR=gross irrigation requirement, $\mathrm{NIR}=$ net irrigation water requirement and $\mathrm{Ea}=$ water application efficiency $=60 \%$.

\subsubsection{Crop and Irrigation Water Requirements Using AquaCrop Model}

Considering groundwater table, as no shallow groundwater table, all stress indicators, waterlogging stress, water shortage stress, air temperature stress, and soil salinity stress have been considered as zero and considering no specific field management, net irrigation requirement and crop water requirement for furrow irrigation have been calculated. The simulation period has been adjusted and soil water profile at $\%$ of RAW considered as an initial condition with no field observation.

To all test crops, crop evapotranspiration has been calculated by multiplying the reference evapotranspiration (ETo) with the crop transpiration coefficient (KcTr) and a water stress coefficient (Ks) which is 1 when water stress does not induce stomatal closure.

Crop transpiration has been calculated by the concept of the following formula

$$
\mathrm{Tr}=\mathrm{Ks}^{*} \mathrm{~K}_{\mathrm{cT}} \mathrm{r}^{*} \mathrm{ETo}
$$

Where, ETo is the reference evapotranspiration, $\mathrm{KcTr}$ is the crop transpiration coefficient, $\mathrm{Ks}$ is a water stress coefficient which is 1 when water stress does not induce stomatal closure.

The crop transpiration coefficient $\mathrm{K}_{\mathrm{cTr}}$ is proportional to the green canopy cover (CC):

$$
\mathrm{K}_{\mathrm{cTr}}=\mathrm{K}_{\mathrm{cTr}, \mathrm{x}} * \mathrm{~K}_{\mathrm{c}} \mathrm{CC} * *
$$

Where, $\mathrm{Kc}_{\mathrm{Tr}, \mathrm{x}}$ is the crop coefficient for maximum crop transpiration (determined by the characteristics that distinguish the crop with a complete canopy cover from the reference grass), and $\mathrm{CC}^{*}$ the canopy cover adjusted for micro-adjective effects.

Net irrigation requirement: The depletion (\% RAW) below which the soil water content in the root zone may not drop ( $0 \%$ RAW corresponds to Field Capacity). The total amount of irrigation water required to keep the water content in the soil profile above the specified threshold is the net irrigation water requirement for the period. The net requirement does not consider extra water that has to be applied to the field to account for conveyance losses or the uneven distribution of irrigation water on the field. 


\subsection{Irrigation Scheduling}

\subsubsection{Irrigation Scheduling Using CropWat Model}

Irrigation scheduling was worked out using CropWat 8.0 windows by selecting two scheduling criteria: fixing the interval and adjusting the depth to a constant value for no yield reduction and minimum water loss and the $100 \%$ readily available soil moisture depletion.

\subsubsection{Irrigation Schedules Using AquaCrop Model}

Generation of irrigation schedules using AquaCrop have been computed by specify back to field capacity and fixed net application depth criterion and fixed interval and allowable depletion ( $\%$ of RAW) time criteria.

By selecting the furrow irrigation method, irrigation events (when to irrigated and how much to irrigate have been specified by considering irrigation water quality for maximum dry yield production and water productivity and minimum labor cost (irrigation event). The electrical conductivity (EC) of the irrigation water was used as an input to irrigation scheduling.

\subsection{Model Calibration and Simulations}

After all, input data encoded - climatic, crop, management, and soil characteristics that described or defined the environment in which the crop was developed. Before the simulation, the simulation phase and the initial conditions at the beginning of the simulation were determined. The user can track changes in the soil water and corresponding changes in the crop development, soil evaporation, transpiration, (ET) rate, biomass production, and yield when running simulation results of the simulation were stored in output files in spreadsheet format to retrieve the data for further processing and analysis. Furthermore, program settings permit the user to change default settings and reset to an individual's default values once more.

Studies have shown that model calibration for several crops had evaluated model performed well and showed that observed data set from the non-water stress conditions (that is full $100 \% \mathrm{ETc}$ irrigation treatment) used for model calibration [13, 15, 16, 20, 19]. The observed crop characteristics namely; time to emergence, time to attain maximum canopy cover, time to flowering, and senescence and physiological maturity (in calendar days) were used. After the calibration process, the model was validated from separated other treatment data except for $100 \%$ ETc [36].

\subsection{Performance Evaluation of Models}

The output of a model depends on the principle of the model itself and the accuracy of the input data. Evaluation of model performance should include both statistical criteria and graphical display. A model is a good representation of reality only if it predicts an observable phenomenon with acceptable accuracy and precision [27].

According to Addicott and Whitmor, [2], it is concluded that any one method of measuring discrepancy between model output and observed data alone might be misleading, but several methods used together could summarize the closeness of a model's estimates and measurements with the observed values. The following statistics and model performance indicators were used to indicate overall model performance: average deviation, root mean square error (RMSE), relative error, model efficiency [3, 18, 26, 25].

Model performance was evaluated using the following statistical parameters: prediction error (Pe), Nash-Sutcliffe efficiency index (E), mean absolute error (MAE), root mean square error normalized (RMSEN).

$$
\text { Prediction error }(\mathrm{Pe}): \frac{(\mathrm{Si}-\mathrm{Oi})}{\mathrm{Oi}} * 100
$$

Where, Si the is predicted value, Oi is observed value.

Root mean square error normalized (RMSEN)

The scientific evidence has indicated that RMSE is expressed in the units of the studied variable; it does not allow model testing under a wide range of metro-climatic conditions [21]. Therefore, RMSE can be normalized using the mean of the observed variable (Oi). The Normalized RMSE expressed in percent, will be calculated as illustrated in (Equation 7) as reported by Lemma Dessalegn and Shimeles Aklilu. [27]. A model can be considered excellent if NRMSE is smaller than $10 \%$, good if between 10 and $20 \%$, fair if between 20 and $30 \%$ and poor if larger than $30[3,37]$.

$$
\mathrm{RMSEN}=\frac{1}{O i} \sqrt{\sum \frac{(S i-O i)^{2} * 100}{N}}
$$

Where, $\mathrm{Si}$ is predicted value, $\mathrm{Oi}$ is observed value, and $\mathrm{N}$ is the number of observations.

Model efficiency

The robustness of the model was assessed with the model efficiency (ME) (Loague and Green 1991).

$$
\mathrm{MF}=\frac{\sum_{i=1}^{N}(o i-\mathrm{mo})^{2}-\sum_{i=1}^{N}(s i-o i)^{2}}{\sum_{i=1}^{N}(o i-m o)^{2}}
$$

Where, $\mathrm{Si}$ is predicted value, oi is the observed value, $\mathrm{N}$ is a number of observations and $\mathrm{MO}$ is the average of the observed values.

ME acquires values from infinite negative to 1 . The closer it gets to 1 , the higher the robustness of the model. An ideal value of MF is the unit.

Nash-Sutcliffe efficiency index

The Nash-Sutcliffe coefficient of efficiency coefficient (NSE) determines the relative magnitude of the residual variance compared to the variance of the observations. A plot of observed data versus simulated data is that too fits the $1: 1$ line indicates a perfect match between the model and the observations. Nash-Sutcliffe was as accurate as of the average of the observed data. A negative NSE occurs when the mean of the observations is a better prediction than the model [3, 37]. The Nash-Sutcliffe coefficient of efficiency coefficient (NSE) calculated as (Equation 9). Nash-Sutcliffe is very commonly used, which means that there are a large number of reported values available in the literature [33]. However, like NSE is not very sensitive to systematic over-or underestimations by the model [25]. 


$$
\mathrm{NSE}=1-\frac{\sum_{i=1}^{N}(s i-o i)^{2}}{\sum_{i=1}^{N}(o i-m o)^{2}}
$$

Where, $\mathrm{Si}$ is predicted value, oi is the observed value, $\mathrm{N}$ is the number of observations and Mo is the average of the observed values.

\section{Results and Discussion}

\subsection{Climate Characteristics of the Study Area}

Long -term climatic data of the study area was analyzed and reference evapotranspiration (ETo) was calculated based on the FAO Penman-Monteith method [6] and the results are given in the following figure 1.

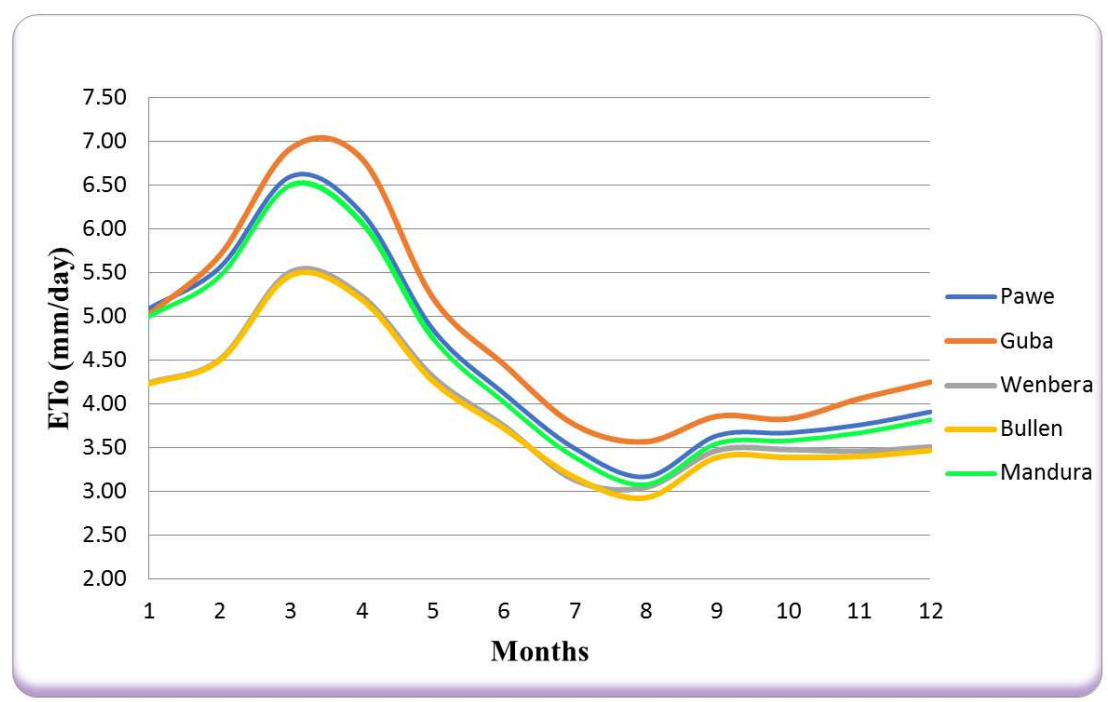

Figure 2. Long term evapotranspiration (ETo) of the study areas (1987-2011).

As shown in Figure 2, the average $\mathrm{ET}_{\mathrm{O}}$ value simulated using CropWat in Pawe district was found to be 4.50 $\mathrm{mm} /$ day. The maximum value of $\mathrm{ET}_{\mathrm{O}}$ was found to be 6.60 $\mathrm{mm} /$ day in March and the minimum $\mathrm{ET}_{\mathrm{O}}$ was $3.17 \mathrm{~mm} /$ day in August. The average $\mathrm{ET}_{\mathrm{O}}$ value simulated using CropWat in Mandura district was $4.51 \mathrm{~mm} /$ day. The average $\mathrm{ET}_{\mathrm{O}}$ value simulated using aqua crops in Mandura district was 4.13 $\mathrm{mm}$ /day. The average $\mathrm{ET}_{\mathrm{O}}$ value simulated using CropWat in Guba district was found to be $4.79 \mathrm{~mm} /$ day. The maximum value of $\mathrm{ET}_{\mathrm{O}}$ was found to be $6.92 \mathrm{~mm} /$ day in March and the minimum $\mathrm{ET}_{\mathrm{O}}$ was $3.57 \mathrm{~mm} /$ day in August.

The average $\mathrm{ET}_{\mathrm{O}}$ values simulated using CropWat in Bullen district were found to be $3.93 \mathrm{~mm} /$ day. The maximum values of $\mathrm{ET}_{\mathrm{O}}$ were $5.47 \mathrm{~mm} /$ day in March and the minimum was 2.93 $\mathrm{mm} /$ day in August using CropWat. The average $\mathrm{ET}_{\mathrm{O}}$ value simulated using CropWat in Wembera district was found to be $3.97 \mathrm{~mm} /$ day. The maximum value of $\mathrm{ET}_{\mathrm{O}}$ was found to be 5.51 $\mathrm{mm} /$ day in March and the minimum was $3.05 \mathrm{~mm} /$ day in August.

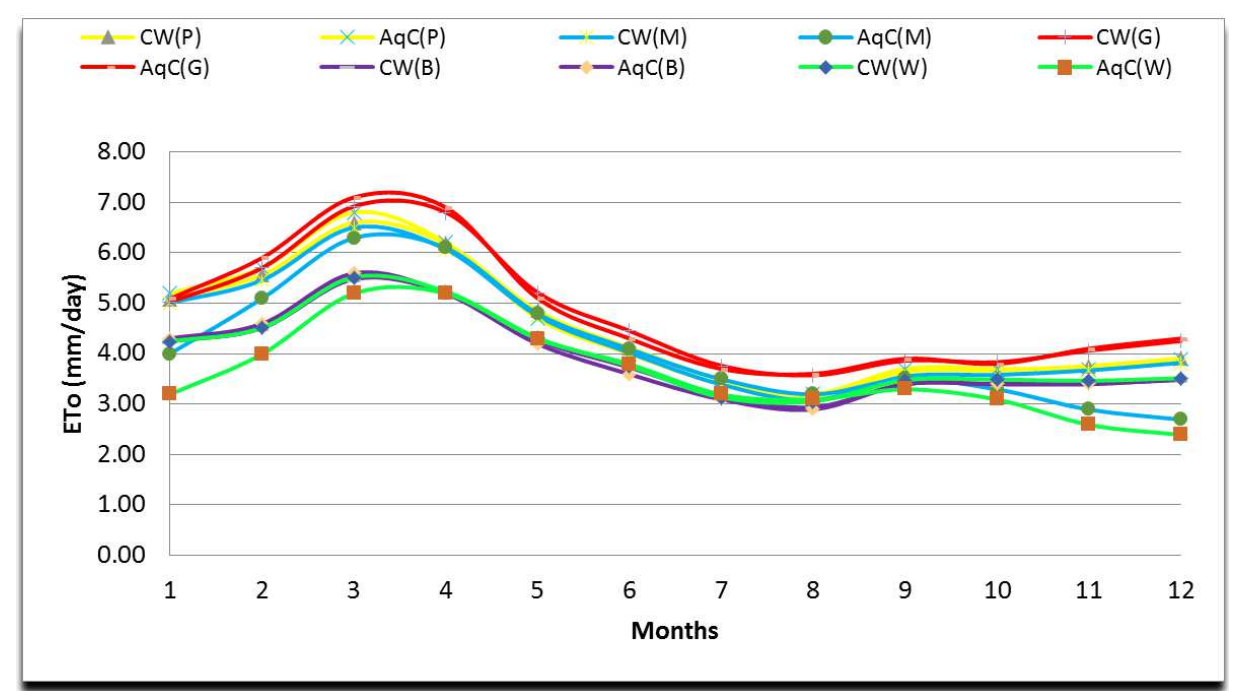

Figure 3. Comparison of CropWat and AquaCrop daily ETo of the study areas.

* $\mathrm{CW}(\mathrm{P})=$ CropWat of Pawe, AqC $(\mathrm{P})=\mathrm{AquCrop}$ of Pawe, $\mathrm{CW}(\mathrm{M})=$ CropWat of Mandura, AqC $(\mathrm{M})=\mathrm{AquCrop}$ of Mandura, $\mathrm{CW}(\mathrm{G})=\mathrm{CropWat}$ of Guba, AqC $(\mathrm{G})=$ AquCrop of Guba, $\mathrm{CW}(\mathrm{B})=$ CropWat of Bullen, $\mathrm{AqC}(\mathrm{B})=\mathrm{AquCrop}$ of Bullen and CW $(\mathrm{W})=$ CropWat of Wombera, AqC $(\mathrm{W})=\mathrm{AquCrop}$ of Wombera. 
As shown in Figure 3, the average $\mathrm{ET}_{\mathrm{O}}$ value simulated using aqua crops in Pawe was found to be $4.52 \mathrm{~mm} / \mathrm{day}$. The maximum value of $\mathrm{ET}_{\mathrm{O}}$ was found to be $6.80 \mathrm{~mm} /$ day in March and the minimum $\mathrm{ET}_{\mathrm{O}}$ was $3.2 \mathrm{~mm} /$ day in August. The relative difference between average ETo values simulated using CropWat and AquaCrop was found to be small which was 0.02 $\mathrm{mm} /$ day. The climate parameters were collected from the Pawe agricultural research center metrology station that was located at a longitude of $36.05^{\circ}$ easts, the latitude of $11.15^{\circ}$ north, and an altitude of 1120 meters above sea level.

The maximum value of $\mathrm{ET}_{\mathrm{O}}$ in Mandura using AquaCrop was $6.30 \mathrm{~mm} /$ day in March and the minimum $\mathrm{ET}_{\mathrm{O}}$ was 3.20 $\mathrm{mm}$ /day in August. The relative difference between average ETo values simulated using Cropwat and AquaCrop was found to be $0.38 \mathrm{~mm} /$ day. The climate parameters were collected from Mandura district metrology station that was located at a longitude of $36.32^{\circ}$ East, the latitude of $11.06^{\circ}$ North, an altitude of 1161 meters above sea level.

The average $\mathrm{ET}_{\mathrm{O}}$ value simulated using AquaCrop was found to be in the Guba district was found to be 4.82 $\mathrm{mm} /$ day. The maximum value of $\mathrm{ET}_{\mathrm{O}}$ was $7.1 \mathrm{~mm} /$ day in March and the minimum $\mathrm{ET}_{\mathrm{O}}$ was $3.6 \mathrm{~mm}$ /day in August. The relative difference between average ETo values simulated using CropWat and AquaCrop was found to be small which was $0.03 \mathrm{~mm} /$ day. The climate parameters were collected from the Guba district metrology station that was located at a longitude of $35.40^{\circ}$ East, the latitude of $11.05^{\circ}$ North, an altitude of 977 meters above sea level in the Guba district.

The average $\mathrm{ET}_{\mathrm{O}}$ values simulated AquaCrop in Bullen district were found to be $3.93 \mathrm{~mm} /$ day. There was no difference between $\mathrm{ET}_{\mathrm{O}}$ average values simulated using CropWat and
Aqua Crops. The maximum values of $\mathrm{ET}_{\mathrm{O}}$ using aqua crop the maximum values of $\mathrm{ET}_{\mathrm{O}}$ was $5.6 \mathrm{~mm}$ /day in March and minimum was $2.9 \mathrm{~mm}$ /day in August, The climate parameters were collected from Bullen district metrology station that was located at the longitude of $36.96^{\circ}$ East, the latitude of $10.50^{\circ}$ North, an altitude of 1323 meter above sea level.

The average $\mathrm{ET}_{\mathrm{O}}$ value simulated using aqua crops in the Wembera district was found to be $3.62 \mathrm{~mm} /$ day. The maximum values of $\mathrm{ET}_{\mathrm{O}}$ were $5.2 \mathrm{~mm} /$ day in March and the minimum was $3.10 \mathrm{~mm} /$ day in August. The relative difference between average ETo values simulated using CropWat and AquaCrop were found to be $0.35 \mathrm{~mm} / \mathrm{day}$. The climate parameters were collected from Debre Zeit metrology station that was located at a longitude of $36.96^{\circ}$ east, the latitude of $10.50^{\circ}$ north, and an altitude of 1323 meters above sea level in Wembera district.

As General, the maximum reference evapotranspiration in the study area estimated using CropWat was found to be 6.92 $\mathrm{mm}$ /day in $G u b a$, and minimum reference evapotranspiration was found to be $2.93 \mathrm{~mm} /$ day in Bullen district. The maximum reference evapotranspiration in the study areas simulating using aqua crops was found to be $7.1 \mathrm{~mm} /$ day in Guba and minimum reference evapotranspiration was found to be $2.9 \mathrm{~mm} /$ day in Bullen district.

\subsection{Crop and Irrigation Water Requirements of Maize in Project Area}

\subsubsection{Crop and Irrigation Water Requirements of Maize Using CropWat Model}

The crop water requirement (ETc) throughout the growing season was then determined based on equation 8 .

Table 1. Crop characteristics and input data used for CropWat.

\begin{tabular}{|c|c|c|c|c|c|}
\hline \multirow{2}{*}{ Crop characteristics } & \multicolumn{4}{|c|}{ Growing stages } & \multirow{2}{*}{ Total } \\
\hline & Initial & Development & Mid & Late & \\
\hline $\mathrm{Kc}$ & 0.45 & & 1.2 & 0.85 & \\
\hline Stages & 20 & 35 & 40 & 30 & 125 \\
\hline Rooting depth & 0.3 & & 1 & & \\
\hline Critical depletion (fraction) & 0.55 & 0.55 & & 0.8 & \\
\hline Yield response factor & 0.4 & 0.4 & 1.3 & 0.5 & 1.25 \\
\hline Crop height & & 2 (optional) & & & \\
\hline
\end{tabular}

As shown in Table 1, since there was no determined crop coefficient, rooting depth, critical depletion, and yield response factor, so far for this area, the FAO recommended values for growth stages are used to calculate CWR and to made irrigation scheduling. The local planting date of the crops had been used for the computation.

Table 2. Simulated ETc and IR of crops in the study areas using CropWat.

\begin{tabular}{llll}
\hline District & ETC $(\mathbf{m m})$ & ER $(\mathbf{m m})$ & IR $(\mathbf{m m})$ \\
\hline Pawe & 680.4 & 12.4 & 667.5 \\
Mandura & 680.3 & 15.2 & 664.3 \\
Guba & 702.4 & 10.3 & 690.8 \\
Bullen & 572.6 & 21.3 & 539.9 \\
Wembera & 576.5 & 185 & 393 \\
\hline
\end{tabular}

* $\mathrm{ETC}=$ Crop water requirement, $\mathrm{ER}=$ Effective rainfall, $\mathrm{IR}=$ Irrigation requirement
As shown in Table 2, the maximum seasonal irrigation requirement of maize was found to be $690 \mathrm{~mm}$ in Guba district and minimum irrigation requirement of $393 \mathrm{~mm}$ in Wombera district. Relatively height amount of the required water was satisfied by rain that occurred in December, January, February and March in Wembera district since this area is located in height altitude and height rainfall area. Seasonal effective rain (Pe) was $185 \mathrm{~mm}$ respectively in Wembera district. In Abshege Woreda, Gurage Zone, Ethiopia, the Crop water requirement of maize estimated using CROPWAT 8.0 for a window with a growing period of 140 days to maturity would require $423 \mathrm{~mm}$ depth of water, while $101 \mathrm{~mm}$ would be required as supplementary irrigation depth [35]. Biniam Yaziz and Tesfaye Tefera [9] reported that the total crop water requirement of maize was $535.60 \mathrm{~mm}$ in Tepi, Southwest of Ethiopia. 


\subsubsection{Crop and Irrigation Water Requirements of Maize Using the AquaCrop Model}

Table 3. Crop characteristics \& input parameters used as input for AquaCrop.

\begin{tabular}{lll}
\hline Crop characteristics & Descriptions & Input Parameter \\
\hline \multirow{3}{*}{ Initial canopy } & Initial canopy cover (\%) & 0.29 \\
& Canopy size seedling (c.m²/plant) & 6.5 \\
& Plant density (plants/ha) & 44,444 \\
& Maximum canopy cover (\%) & 90 \\
Development & From day 1 after sowing to emergence (day) & 8 \\
& Maximum canopy (day) & 50 \\
& Senescence (day) & 95 \\
Flowering & Maturity (day) & 525 \\
and yield formation (root/tuber & Length building up of harvest index (day) & 13 \\
formation) & Duration of flowering (day) & 68 \\
& From day 1 after sowing to flowering (day), yield formation & 1.2 \\
Root deepening & Maximum effective root depth (m) & 97 \\
& From day 1 after sowing to maximum root depth (day) & 1.1 \\
\hline
\end{tabular}

As shown in Table 3, Some maize characteristics used as input for AquaCrop model have been taken with minimum calibration from the reference manual developed with contributions of the AquaCrop network in January 2009 as indicated [11], the experiments used for calibration and validation crops including maize were generally conducted under high levels of management, with the control treatments aimed at production levels close to the maximum potential achievable in that location. Most of the recent scientific evidences have indicated that also for onion and pepper characteristics should take with minimum calibration [24, 30].

Table 4. Simulated NIR, WP, and DY of maize in the study areas using AquaCrop.

\begin{tabular}{|c|c|c|c|c|c|}
\hline \multirow{2}{*}{ Parameters } & \multicolumn{5}{|c|}{ Districts } \\
\hline & Pawe & Mandura & Guba & Bullen & Wombera \\
\hline NIR (mm) & 673.1 & 569 & 618 & 548.8 & 309 \\
\hline $\mathrm{ET}_{\mathrm{C}}(\mathrm{mm})$ & 593.9 & 502.1 & 565 & 484.6 & 425 \\
\hline DY (ton/ha) & 11.349 & 12.013 & 12.013 & 11.738 & 12.167 \\
\hline WP $\left(\mathrm{kg} / \mathrm{m}^{3}\right)$ & 1.97 & 2.47 & 2.18 & 2.51 & 2.98 \\
\hline $\mathrm{P}(\%)$ & 23 & 23 & 21 & 26 & 32 \\
\hline ETo (mm) & 678.4 & 570.8 & 705.3 & 565.5 & 467.8 \\
\hline
\end{tabular}

*Net=net irrigation requirement, $\mathrm{ETc}=$ crop water requirement, $\mathrm{DR}=\mathrm{dry}$ yield, $\mathrm{Wp}=$ water productivity, $\mathrm{p}=$ allowable root zone depletion for actual production, $\mathrm{ETo}=$ reference evapotranspiration,

As shown in Table 4, the maximum net requirement of maize was found to be $673 \mathrm{~mm}$ in Pawe district and the minimum net irrigation requirement was found to be $309 \mathrm{~mm}$ in Wembera district.

\subsection{Irrigation Scheduling of Maize under Different Districts}

\subsubsection{Irrigation Scheduling of Maize Using CropWat Model}

To carry out irrigation scheduling for selected crops using
CropWat model has different options. These are irritating at fixed intervals per stage time, irrigate at $100 \%$ critical depletion and the refill soil to $100 \%$ field capacity depth criteria. However, based on the research evidence and field data available in the study area irrigate at fixed interval per stage time criteria was used. Irrigation efficiency of $60 \%$ was selected since main irrigation application methods for the area is surface irrigation especially furrow irrigation.

Table 5. Irrigation scheduling of maize in Pawe using irrigate at a fixed interval.

\begin{tabular}{|c|c|c|c|c|c|c|c|}
\hline Date & Stage & NIR (mm) & GIR (mm) & Date & Stage & NIR (mm) & GIR (mm) \\
\hline 10 December & Initial & 40.2 & 67 & 8 February & Mid & 65.6 & 109.3 \\
\hline 20 December & Initial & 28.3 & 47.2 & 18 February & Mid & 67.7 & 112.8 \\
\hline 30 December & Dev & 35.4 & 59 & 28 February & Mid & 70.8 & 118 \\
\hline 9 January & Dev & 46.1 & 76.8 & $10 \mathrm{March}$ & End & 74.8 & 124.7 \\
\hline 19 January & Dev & 58.6 & 97.7 & 20 March & End & 71.8 & 119.6 \\
\hline 29 January & Mid & 64.8 & 108 & 30 March & End & 59.5 & 99.1 \\
\hline
\end{tabular}

$* \mathrm{NIR}=$ net irrigation requirement, $\mathrm{GIR}=\mathrm{Gross}$ irrigation requirement

As shown in Table 5, irrigation scheduling of maize in Pawe using fixed interval (10 days) per stage time criteria and refill soil to field capacity depth criteria had 12 irrigation events. The total gross and net irrigation requirements were 1123.7 
$\mathrm{mm}$ and $674.2 \mathrm{~mm}$ respectively with a yield reduction of $0.0 \%$.

Table 6. Irrigation scheduling of maize in Mandura using irrigate at a fixed interval.

\begin{tabular}{llllllll}
\hline Date & Stage & NIR $(\mathbf{m m})$ & GIR $(\mathbf{m m})$ & Date & Stage & NIR $(\mathbf{m m})$ & GIR $(\mathbf{m m})$ \\
\hline 10 December & Initial & 33.6 & 56 & 8 February & Mid & 65.2 & 108.6 \\
20 December & Initial & 26.6 & 44.3 & 18 February & Mid & 67.2 & 112 \\
30 December & Dev & 33.6 & 56 & 28 February & Mid & 70.3 & 117.2 \\
9 January & Dev & 44.1 & 73.4 & 10 March & End & 75.2 & 125.3 \\
19 January & Dev & 56.6 & 94.3 & 20 March & End & 72.6 & 120.9 \\
29 January & Mid & 63.7 & 106.2 & 30 March & End & 58.9 & 98.1 \\
\hline
\end{tabular}

* $\mathrm{NIR}=$ Net irrigation requirement, $\mathrm{GIR}=$ gross irrigation requirement, $\mathrm{Dev}=$ Development

As shown in Table 6, irrigation scheduling of maize in Mandura using the fixed interval (10 days) per stage time criteria and refill soil to field capacity depth criteria had 12 irrigation events. The total gross and net irrigation requirements were found to be $1112.4 \mathrm{~mm}$ and $667.4 \mathrm{~mm}$ respectively with yield reduction of $0.1 \%$.

Table 7. Irrigation scheduling of maize in Guba using irrigate at fixed interval.

\begin{tabular}{|c|c|c|c|c|c|c|c|}
\hline Date & Stage & NIR (mm) & GIR (mm) & Date & Stage & NIR (mm) & GIR (mm) \\
\hline 10 December & Initial & 29.7 & 49.5 & 8 February & Mid & 63.8 & 106.3 \\
\hline 20 December & Initial & 27.9 & 46.6 & 18 February & Mid & 65.8 & 109.7 \\
\hline 30 December & Dev & 34.2 & 57.1 & 28 February & Mid & 68.5 & 114.2 \\
\hline 9 January & Dev & 43.8 & 73 & 10 March & End & 72.7 & 121.1 \\
\hline 19 January & Dev & 54.4 & 90.6 & $20 \mathrm{March}$ & End & 74.2 & 123.7 \\
\hline 29 January & Mid & 61.9 & 103.1 & 30 March & End & 63.6 & 105.9 \\
\hline
\end{tabular}

* NIR=Net irrigation requirement, GIR=gross irrigation requirement, Dev=Development

Irrigation scheduling of maize in Guba using the fixed interval (10 days) per stage time criteria and refill soil to field capacity depth criteria had 12 irrigation events and had the total gross and net irrigation requirement of $1100.7 \mathrm{~mm}$ and $660.4 \mathrm{~mm}$ respectively as shown in table 7 .
The yield reduction was high (4.4\%) since soil texture of Guba district was sandy as shown in table 7, that need irrigation schedule using short irrigation intervals and small amount of water. So irrigation interval less than 10 days can be used by considering labor cost to reduce yield reduction.

Table 8. Irrigation scheduling of maize in Bullen using irrigate at a fixed interval.

\begin{tabular}{lllllll}
\hline Date & Stage & NIR $(\mathbf{m m})$ & GIR $(\mathbf{m m})$ & Date & Stage & NIR $(\mathbf{m m})$ \\
\hline 10 December & Initial & 32.4 & 53.9 & 8 February & Mid & 52.3 \\
20 December & Initial & 24.1 & 40.2 & 18 February & Mid & 53.6 \\
30 December & Dev & 29.5 & 49.1 & 28 February & Mid & 56.7 \\
9 January & Dev & 37.4 & 62.4 & 10 March & End & 62.1 \\
19 January & Dev & 47.2 & 78.6 & 20 March & End & 60.8 \\
29 January & Mid & 51.9 & 86.5 & 30 March & End & 48.4 \\
\hline
\end{tabular}

* NIR=Net irrigation requirement, GIR=gross irrigation requirement, Dev=Development

As indicated in Table 8, irrigation scheduling of maize in Bullen using the interval (10 days) per stage time criteria and refill soil to field capacity depth criteria had 12 irrigation events and had the total gross and net irrigation requirements of $927.2 \mathrm{~mm}$ and $556.3 \mathrm{~mm}$ respectively with no yield reduction.

Table 9. Irrigation scheduling of maize in Wembera using irrigate at a fixed interval.

\begin{tabular}{|c|c|c|c|c|c|c|c|}
\hline Date & Stage & NIR (mm) & GIR (mm) & Date & Stage & NIR (mm) & GIR (mm) \\
\hline 10 December & Initial & 26 & 43.4 & 8 February & Mid & 37.2 & 62.1 \\
\hline 20 December & Initial & 13.6 & 22.7 & 18 February & Mid & 37.5 & 62.5 \\
\hline 30 December & Dev & 18 & 30.1 & 28 February & Mid & 41.6 & 69.3 \\
\hline 9 January & Dev & 26 & 43.3 & 10 March & End & 47.6 & 79.3 \\
\hline 19 January & Dev & 36.9 & 61.5 & $20 \mathrm{March}$ & End & 47.2 & 78.6 \\
\hline 29 January & Mid & 39.4 & 65.6 & 30 March & End & 38.4 & 64.1 \\
\hline
\end{tabular}

* $\mathrm{NIR}=$ Net irrigation requirement, $\mathrm{GIR}=$ gross irrigation requirement, $\mathrm{Dev}=\mathrm{Development}$

As shown in Table 9, Irrigation scheduling of maize in Wembera using the fixed interval (10 days) per stage time criteria and refill soil to field capacity depth criteria had 12 irrigation events and had the total gross and net irrigation requirement of $655.8 \mathrm{~mm}$ and $393.5 \mathrm{~mm}$ respectively with no yield reduction.

Research conducted in Vertisol in Metekel Zone, NorthWest of Ethiopia during the summer seasonal (January first to 
May fifth) indicated that CWR, IR, NIR and GIR requirements of maize with total growth stages of 125 days were found to be $502 \mathrm{~mm}, 486.8 \mathrm{~mm} 478.5 \mathrm{~mm}$ and 651.1 $\mathrm{mm}$ respectively and relatively high yield was recorded using irrigating at fixed interval 14 days per stage time criteria and refill soil to field capacity depth criteria [7].

\subsubsection{Irrigation Scheduling of Maize Using the AquaCrop Model}

Generating irrigation schedules is a practical mode for planning or evaluating a potential irrigation strategy. In this mode, AquaCrop will generate at run time irrigations according to the specified time and a depth criterion.

Table 10. Irrigation scheduling of maize in the study area at a fixed interval.

\begin{tabular}{|c|c|c|c|c|c|c|c|}
\hline \multirow{2}{*}{ Irrigation event } & \multirow{2}{*}{ DAP } & \multicolumn{5}{|c|}{ NAD (mm) } & \multirow{2}{*}{$\begin{array}{l}\mathrm{EC}_{W} \\
(\mathrm{ds} / \mathrm{m})\end{array}$} \\
\hline & & Pawe & Mandura & Guba & Bullen & Wembera & \\
\hline 1 & 10December & 27.6 & 43.2 & 32.8 & 46.2 & 38.2 & 0.4 \\
\hline 2 & 20 December & 25.5 & 32.2 & 21.7 & 35.3 & 21.2 & 0.4 \\
\hline 3 & 30 December & 25.2 & 29.4 & 25.2 & 36.3 & 18.9 & 0.4 \\
\hline 4 & 9 January & 46.3 & 43.9 & 43.8 & 46.7 & 23.8 & 0.4 \\
\hline 5 & 19 January & 54.4 & 49.5 & 56.6 & 50.9 & 26.9 & 0.4 \\
\hline 6 & 29 January & 55.8 & 52.6 & 60.2 & 52.1 & 30.3 & 0.4 \\
\hline 8 & 18 February & 56.7 & 56.7 & 62.9 & 52.8 & 31.1 & 0.4 \\
\hline 9 & 28 February & 57.5 & 58.7 & 64.5 & 53.8 & 30.5 & 0.4 \\
\hline 10 & 10 March & 61.8 & 60.6 & 66.9 & 56.5 & 36.3 & 0.4 \\
\hline 11 & 20 March & 51.9 & 46.6 & 51 & 41.7 & 32.1 & 0.4 \\
\hline 12 & 30 March & 26.6 & 24.1 & 20.3 & 19.3 & 17.5 & 0.4 \\
\hline IR (mm) & & 655.1 & 552.3 & 567.5 & 534.8 & 337 & \\
\hline Rain (mm) & & 12.3 & 15 & 12.5 & 23.5 & 196.7 & \\
\hline DY (T/ha) & & 11.883 & 11.858 & 11.803 & 11.635 & 11.736 & \\
\hline $\mathrm{Wp}\left(\mathrm{kg} . / \mathrm{m}^{3}\right)$ & & 2.21 & 2.65 & 2.43 & 2.69 & 2.94 & \\
\hline
\end{tabular}

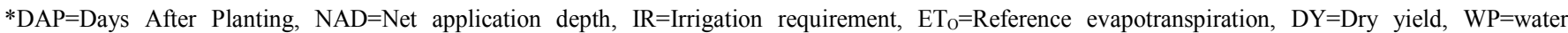
productivity, $\mathrm{EC}_{\mathrm{W}}=$ Electrical conductivity of irrigation water.

As shown in Table 10, to generate irrigation scheduling of maize, a fixed interval of 10 days' time criterion and refill soil to field capacity depth criteria which had 12 irrigation events. The simulation indicated CWR of 655.1, 552.3, 567.5, 534.8 and $337 \mathrm{~mm}, 11.643,11.858,11.803,11.635$, and $11.736 \mathrm{t} / \mathrm{ha}$ of maize can be produced in Pawe, Mandura, Guba, Bullen, and Wembera respectively. In Bushland the study that was conducted in 1989 shows that crop water requirement of maize simulated using AquaCrop was 598.0 $\mathrm{mm}$ in areas where measured crop water requirement of maize was $625.0 \mathrm{~mm}$ and in 1990 crop water requirement of maize simulated using AquaCrop was $730.8 \mathrm{~mm}$ in areas where the measured value was $778.3 \mathrm{~mm}$. [26]. During the 'driest' year, seasonal (March to mid-September) rainfall $(138 \mathrm{~mm})$ and ETo $(682 \mathrm{~mm})$ resulted in irrigation needs of onion in were found to be $286 \mathrm{~mm}$ and $360 \mathrm{~mm}$ for the sandy and sandy loam soils, respectively [30].

\subsection{Performance Evaluation of Models}

Considering the districts as a number of observations RMSE values of maize when simulating crop water requirement was fund to be 133.5. Considering the number of irrigation events as a number of observations, the magnitude of root means square errors when simulating irrigation scheduling for maize in each irrigation event was found to be 4.09, 4.39, 4.26, 5.17, 3.12 in Pawe, Mandura Guba Bullen, and Wembera respectively annex tables 11 and 12 .

Considering the districts as a number of observations RMSEN values of maize when simulating crop water requirement were found to be $20.74 \%$ and lied between $20 \%$ and $30 \%$ and the simulation was reasonable. The magnitude of all RMSEN values of maize when simulating irrigation scheduling for maize in each irrigation events were found to 7.18\%, 7.88\%, 7.74\%, 9.08\%, 9.13\% in Pawe, Mandura, Guba, Bullen, and Wembera respectively and all values lied than $10 \%$, so the simulation is excellent in each district annexed table 12 . The simulation is considered excellent if RMSEN is less than $10 \%$; it is good if it comes between $10 \%$ and $20 \%$; reasonable when it comes between $20 \%$ and $30 \%$, and poor when it is greater than 30\% [23].

Nash-Sutcliffe efficiency index (NSE) values of maize, when simulating crop water requirements was found to be 0.98 closed to one, which means the model simulation was in the acceptable range. The relative magnitude of the residual variance compared to the variance of the observations was small. The magnitude of NSE when simulating irrigation scheduling for Maize in each irrigation event was found to $0.1,0.12,0.16,-0.44,-0.08$ in Pawe, Mandura, Guba, Bullen, and Wembera respectively as annexed in tables 11 and 12. All values were close to one and the simulation was accurate.

The magnitude of model efficiency (MF) values when simulating irrigation scheduling for maize in each irrigation event was found to $0.1,0.12,0.16,-0.44,-0.08$ in Pawe, Mandura, Guba, Bullen, and Wembera respectively. The negative value of Model efficiency indicates overestimation. And positive values indicate underestimation. Ideally, model efficiency (MF) will be zero. The model efficiency of maize when simulating crop water requirements was 0.98 . When $\mathrm{Pe}$, approaches zero, they represent positive indicators of 
model performance and used to evaluate the model prediction error. Pe used to define the robustness of the model as well as to predict the values. Pe values of maize when simulating total crop water requirements were found to be $-0.13,-0.26$, $0.19,-0.15$, and -0.26 in Pawe, Mandura, Guba, Bullen, and Wembera respectively. But $\mathrm{Pe}$ values when simulating irrigation scheduling maize in each irrigation event were found to be $-0.2,-0.17,-0.14,-0.2$, and -0.17 in Pawe, Mandura Guba Bullen, and Wembera respective and annexed in tables 11 and 12.

\section{Conclusions and Recommendation}

This study was aimed to compare estimation methods of crop water requirement and irrigation scheduling for major crops using different models and compare the significance of models for adoption at different situations in Metekel zone. It is observed that the maximum reference evapotranspiration in the study area was found to be $7.1 \mathrm{~mm} /$ day in $G u b a$ and minimum reference evapotranspiration was $2.9 \mathrm{~mm} /$ day in Bullen district. In all cases, the maximum ETo in all districts was fund to in March and the lowest in August. The maximum ETc was found to be $702.4 \mathrm{~mm}$ respectively in Guba district and minimum ETc was found to be $572.6 \mathrm{~mm}$ in Bullen district respectively using CropWat but the effective rainfall $(\mathrm{Pe})$ was determined as $185 \mathrm{~mm}$ in Wembera district. However, using the AquaCrop model the maximum ETc was recorded for maize $565 \mathrm{~mm}$ in Guba but a minimum of 425 $\mathrm{mm}$, was recorded in Wembera district. The study revealed that the irrigation scheduling with a fixed interval criterion for maize 10 days with 12 irrigation events has been determined. Moreover, furrow irrigation with $60 \%$ irrigation application efficiency was adjusted during irrigation water applications for all districts. It has been observed that there were a strong relationship and a significant relation between the simulated and observed values for validation. Hence, Normalized Root mean square errors (NRMSE), model by Nash-Sutcliffe efficiency (NSE), Prediction error (Pe), and Model efficiency (MF) showed that the model well simulated in all parameters considered.

AquaCrop model is very useful and well simulate for the study area under different climatic conditions. Therefore, this model is recommended due to its merit that a user friendly, easy for-an application, accuracy, and robustness and address the conditions where water is a key limiting factor for crop production, climate change, and different field management options to enhance water productivity. Scheduling irrigation water using the AquaCrop model is found to improve water productivity. It is thus advisable to use the AquaCrop model in to the development action at scale through developing appropriate packages and extension guidelines. It is recommended that farmers and end-users should adopt fixed irrigation intervals for irrigated maize in the study area to save water, time, labor, and energy during irrigation water application.

\section{Appendix}

Table 11. Performance Evaluation of Models to Simulate CWR for maize in different districts.

\begin{tabular}{|c|c|c|c|c|c|c|c|}
\hline District & Si & $\mathbf{O i}$ & (Si-Oi) & $(\mathrm{Si}-\mathrm{Oi}) / \mathbf{O i}$ & $(\mathrm{Si}-\mathrm{Oi})^{2}$ & (Oi- 01̃) & $(\mathrm{Oi}-\mathrm{O} \overline{1})^{2}$ \\
\hline Pawe & 593.9 & 680.4 & -86.5 & -0.12713 & 7482.25 & 37.96 & 1440.962 \\
\hline Mandura & 502.1 & 680.3 & -178.2 & -0.26194 & 31755.24 & 37.86 & 1433.38 \\
\hline Guba & 565 & 702.4 & -137.4 & -0.19562 & 18878.76 & 59.96 & 3595.202 \\
\hline Bullen & 484.6 & 572.6 & -88 & -0.15368 & 7744 & -69.84 & 4877.626 \\
\hline Wembera & 425 & 576.5 & -151.5 & -0.26279 & 22952.25 & -65.94 & 4348.084 \\
\hline Sum & 2570.6 & 3212.2 & -641.6 & -1.00116 & 88812.5 & 37.96 & 6603666 \\
\hline Mean & 514.12 & 642.44 & -128.32 & -0.20023 & 17762.5 & 37.86 & 1440.962 \\
\hline RMSE & & & 133.5 & & & & \\
\hline NSE & & & 0.98 & & & & \\
\hline MF & & & 0.99 & & & & \\
\hline $\mathrm{Pe}$ & & & -0.2 & & & & \\
\hline
\end{tabular}

Table 12. Performance Evaluation of Models to Simulate Irrigation Scheduling of maize under different districts of study areas.

\begin{tabular}{|c|c|c|c|c|c|c|c|c|c|}
\hline Maize & Pawe & & & Mand & & & Guba & & \\
\hline DAP & $\mathbf{O i}$ & $\mathbf{S i}$ & $(\mathrm{Si}-\mathrm{Oi})^{2}$ & $\mathbf{O i}$ & Si & $(\mathrm{Si}-\mathrm{Oi})^{2}$ & $\mathbf{O i}$ & $\mathbf{S i}$ & $(\mathrm{Si}-\mathrm{Oi})^{2}$ \\
\hline 10-Dec & 40.2 & 27.6 & 158.76 & 33.6 & 43.2 & 92.16 & 29.7 & 32.8 & 9.61 \\
\hline 20-Dec & 28.3 & 25.5 & 7.84 & 26.6 & 32.2 & 31.36 & 27.9 & 21.7 & 38.44 \\
\hline 30-Dec & 35.4 & 25.2 & 104.04 & 33.6 & 29.4 & 17.64 & 34.2 & 25.2 & 81 \\
\hline 9-Jan & 46.1 & 46.3 & 0.04 & 44.1 & 43.9 & 0.04 & 43.8 & 43.8 & 0 \\
\hline 19-Jan & 58.6 & 54.4 & 17.64 & 56.6 & 49.5 & 50.41 & 54.4 & 56.6 & 4.84 \\
\hline 29-Jan & 64.8 & 55.8 & 81 & 63.7 & 52.6 & 123.21 & 61.9 & 60.2 & 2.89 \\
\hline 18-Feb & 67.7 & 56.7 & 121 & 67.2 & 56.7 & 110.25 & 65.8 & 62.9 & 8.41 \\
\hline 28-Feb & 70.8 & 57.5 & 176.89 & 70.3 & 58.7 & 134.56 & 68.5 & 64.5 & 16 \\
\hline 10-Mar & 74.8 & 61.8 & 169 & 75.2 & 60.6 & 213.16 & 72.7 & 66.9 & 33.64 \\
\hline 20-Mar & 71.8 & 51.9 & 396.01 & 72.6 & 46.6 & 676 & 74.2 & 51 & 538.24 \\
\hline 30-Mar & 59.5 & 26.6 & 1082.41 & 58.9 & 24.1 & 1211.04 & 63.6 & 20.3 & 1874.89 \\
\hline Sum & 683.6 & 545.1 & 2410.67 & 667.6 & 552.2 & 2770.08 & 660.5 & 567.5 & 2612.8 \\
\hline Mean & 56.97 & 45.43 & 200.88 & 55.63 & 46.02 & 230.84 & 55.04 & 47.29 & 217.73 \\
\hline
\end{tabular}




\begin{tabular}{|c|c|c|c|c|c|c|c|c|c|}
\hline Maize & Pawe & & & Ma & & & Gul & & \\
\hline DAP & Oi & $\mathbf{S i}$ & $(\mathrm{Si}-\mathrm{Oi})^{2}$ & Oi & $\mathbf{S i}$ & $(\mathrm{Si}-\mathrm{Oi})^{2}$ & $\mathbf{O i}$ & $\mathbf{S i}$ & $(\mathrm{Si}-\mathrm{Oi})^{2}$ \\
\hline $\mathrm{N}$ & 12 & 12 & & 12 & 12 & & 12 & 12 & \\
\hline RMSE & & & 4.09 & & & 4.39 & & & 4.26 \\
\hline NRMSE (\%) & & & 7.18 & & & 7.88 & & & 7.74 \\
\hline NSE & & & 0.1 & & & 0.12 & & & 0.16 \\
\hline MF & & & 0.1 & & & 0.12 & & & 0.16 \\
\hline $\mathrm{Pe}$ & & & -0.2 & & & -0.17 & & & -0.14 \\
\hline
\end{tabular}

Table 12. Continued.

\begin{tabular}{|c|c|c|c|c|c|c|}
\hline Maize & Bullen & & & Womb & & \\
\hline DAP & $\mathbf{O i}$ & $\mathbf{S i}$ & $(\mathrm{Si}-\mathrm{Oi})^{2}$ & Oi & $\mathbf{S i}$ & $(\mathrm{Si}-\mathrm{Oi})^{2}$ \\
\hline 10-Dec & 40.2 & 46.2 & 36 & 26 & 38.2 & 148.84 \\
\hline 20-Dec & 28.3 & 35.3 & 49 & 13.6 & 21.2 & 57.76 \\
\hline 30-Dec & 35.4 & 36.3 & 0.81 & 18 & 18.9 & 0.81 \\
\hline 9-Jan & 46.1 & 46.7 & 0.36 & 26 & 23.8 & 4.84 \\
\hline 19-Jan & 58.6 & 50.9 & 59.29 & 36.9 & 26.9 & 100 \\
\hline 29-Jan & 64.8 & 52.1 & 161.29 & 39.4 & 30.3 & 82.81 \\
\hline 8-Feb & 65.6 & 52.2 & 179.56 & 37.2 & 30.4 & 46.24 \\
\hline 18-Feb & 67.7 & 52.8 & 222.01 & 37.5 & 31.1 & 40.96 \\
\hline 28-Feb & 70.8 & 53.8 & 289 & 41.6 & 30.5 & 123.21 \\
\hline 10-Mar & 74.8 & 56.5 & 334.89 & 47.6 & 36.3 & 127.69 \\
\hline 20-Mar & 71.8 & 41.7 & 906.01 & 47.2 & 32.1 & 228.01 \\
\hline 30-Mar & 59.5 & 19.3 & 1616.04 & 38.4 & 17.5 & 436.81 \\
\hline Sum & 683.6 & 543.8 & 3854.26 & 409.4 & 337.2 & 1397.98 \\
\hline Mean & 56.97 & 45.32 & 321.18 & 34.12 & 28.1 & 116.49 \\
\hline $\mathrm{N}$ & 12 & 12 & & 12 & 12 & \\
\hline RMSE & & & 5.17 & & & 3.12 \\
\hline NRMSE (\%) & & & 9.08 & & & 9.13 \\
\hline NSE & & & -0.44 & & & -0.08 \\
\hline MF & & & -0.44 & & & -0.08 \\
\hline $\mathrm{Pe}$ & & & -0.2 & & & -0.17 \\
\hline
\end{tabular}

\section{References}

[1] Abebaw Assaye, Adane Melak, Birhanu Ayalew, Dessalegn Teshale, Yalew Mazengia. 2015. Assessment of Seed Systems in North Western Ethiopia; With Special Emphasis on Community Based Seed Multiplication Scheme. World Scientific News 12 (2015) 100-110.

[2] Addicott, T. M. and Whitmor, A. P. 1987. Computer simulation of changes in soil mineral nitrogen and crop nitrogen during autumn, winter and spring. J. Agric. Sci. Cambridge, 109: 141-157.

[3] Ahmad, I., Wajid, S. A., Ahmad, A., Cheema, M. J. M., \& Judge, J., 2019. Optimizing irrigation and nitrogen requirements for maize through empirical modeling in semiarid environment. Environ Sci Pollut Res Int, 26 (2), $1227-$ 1237. doi: $10.1007 / \mathrm{s} 11356-018-2772-x$.

[4] Ali, M. H., Amin, M. G. M. and Islam, A. K. M. R. 2004. Comparison of various methods for estimating reference crop evapotranspiration. J. Bangladesh Agril, Uni. 2 (2): 313-324.

[5] Ali, M. H., Paul, H. and Haque, M. R. 2011. Estimation of evapotranspiration using a simulation model. J. Bangladesh Agril. Univ, 9 (2): 257-266.

[6] Allen, R. G., Periera, L. S., Raes, D. and Smith, M. 1998. Crop evapotranspiration. Guidelines for computing crop water requirements (FAO Irrigation and Drainage Paper no. 56, p. 300). Rome.
[7] Ashebir Haile and Demeke Tamene. 2017. Determination of Optimum Irrigation Scheduling and Water Us Efficiency for Maize Production in North-West Ethiopia. Journal of Natural Sciences Research, volume. 7. no. 21. PP 22-27.

[8] Ashebir Haile. 2017. Application of water balance model simulation for water resource assessment in upper blue nile of north Ethiopia using hec-hms by gis and remote sensing: case of beles river basin. Int J Hydro. 2017; 1 (7): 222-227. DOI: 10.15406/ijh.2017.01.00038.

[9] Biniam Yaziz and Tesfaye Tefera. 2016. Determination of Optimal Irrigation Scheduling for Maize (zea mays) at Teppi, Southwest of Ethiopia. International Journal of Research and Innovations in Earth Science Volume 3, Issue 5, ISSN (Online): 2394-1375.

[10] Djaman, Koffi, Irmak, Suat, Rathje, William R, Martin, Derrel L, \& Eisenhauer, Dean E. (2013). Maize evapotranspiration, yield production functions, biomass, grain yield, harvest index, and yield response factors under full and limited irrigation. Transactions of the ASABE, 56 (2), 373-393.

[11] Dirk RAES, Pasquale STEDUTO, Theodore C. HSIAO, and Elias FERERES. 2009. calibration and validation of crops. reference manual. Reference Manual, Annexes - Aqua Crop.

[12] FAO (Food and Agriculture Organization). 2005. Irrigation water requirements: Irrigation Potential in Africa: A Basin Approach, Chapter 5, FAO Corporate Document Repository, FAO, Rome, Italy.

[13] FAO (Food and Agriculture Organization). 1998. Crop evapotranspiration by R. Allen, L. A. Pereira, D. Raes and M. Smith. FAO Irrigation and Drainage Paper No. 56. 
[14] FAO (Food and Agriculture Organization). 1990. Crop water information: potato. Accessed at cropinfo_potato.html. Development Division, Rome, Italy. http://www.fao.org.

[15] Farahani, H. J., Izzi, G., \& Oweis, T. Y. (2009). Parameterization and evaluation of the Aqua Crop model for full and deficit irrigated cotton. Agronomy journal, 101 (3), 469-476.

[16] García-Vila, M., Fereres, E., Mateos, L., Orgaz, F., \& Steduto, P. 2009. Deficit irrigation optimization of cotton with Aqua Crop. Agronomy journal, 101 (3), 477-487.

[17] Geerts, S., Raes, D., Garcia, M., Miranda, R., Cusicanqui, J. A., Taboada, C.,... \& Mamani, J. 2009. Simulating yield response of quinoa to water availability with AquaCrop. Agronomy Journal, 101 (3), 499-508.

[18] George, B., Shende, S., and Raghuwanshi, N. 2000. Development and testing of an irrigation scheduling model. Agricultural Water Management, 46 (2), 121-136.

[19] Guesh T., Nigussie D., and Gebremedhin W., 2015. Growth, Yield, and Quality of Onion (Allium Cepa L.) As Influenced By Intra-Row Spacing And Nitrogen Fertilizer Levels In Central Zone Of Tigray, Northern Ethiopia, master's thesis, Haramaya University, Ethiopia.

[20] Heng, L. K., Hsiao, T., Evett, S., Howell, T., \& Steduto, P. 2009. Validating the FAO AquaCrop model for irrigated and water deficient field maize. Agronomy Journal, 101 (3), 488498.

[21] Hsiao, T. C., L. K., Heng, P., Steduto, B. Rojas-Lara, D. Raes \& E. Fereres. 2009. AquaCrop-The FAO crop model to simulate yield response to water: III. Parameterization and testing for maize. Agron. J. 101: 448-459.

[22] Jacovides C. P and Kontoyiannis H. 1995. Statistical procedures for the evaluation of evapotranspiration computing models, Agricultural Wtaer Management, Volume 27, Issues 3-4, July, Pages 365-371.

[23] Jamieson, P. D., Porter, J. R., \& Wilson, D. R. 1991. A test of computer simulation model ARC-WHEAT 1 on wheat crops grown in New Zealand. Field Crops Research.

[24] JOHN B. ZAYZAY, Jr. 2015. Validation of the FAO aqua crop model for irrigated hot pepper (capsicum frutescens var legon 18 ) in the coastal savannah ecological zone of Ghana. $A$ Thesis Submitted to the Department of Agricultural Engineering, School of Agriculture, College of Agriculture and Nature Sciences, University of Cape Coast.

[25] Krause, P., Boyle, D. P., \& Bäse, F. 2005. Comparison of different efficiency criteria for hydrological model assessment. Advances in geosciences, 5, 89-97.

[26] Lee, K. H., Theodore, H., Steve E., Terry, H., And Pasquale, 2009. Validating The FAO Aquacrop Model for Irrigated and
Water Difficit Field Maize. Agronomy Journal, Volume 101, Issue 3: pp 488-498.

[27] Lemma Dessalegn and Shimeles Aklilu. 2003. Research Experience in Onion Production. Research Report Number, 55, EARO, Addis Ababa, Ethiopia.

[28] Loague, K. and Green, R. E. 1991. Statistical and graphical methods for evaluating solute transport models: Overview and application. J. Contam. Hydrol, 7: 51-73.

[29] Lutaladio, N., Ortiz, O., \& Caldiz, D. (2009). Sustainable potato production. Guidelines for developing countries. Food and Agriculture Organization.

[30] MARTA PEREZ ORTOLA. 2013. Modelling the impacts of in-field soil and irrigation variability on onion yield. School of applied science.

[31] Milander J., Charles Wortmann, Charles Shapiro1, Tim Shaver, Micael Mainz. 2015. Soil Test P Level and Tillage Effect on Corn Yield.

[32] Ministry of Agriculture (MoA) and Agricultural Transformation Agency (ATA). 2013. Realizing the Potential of Household Irrigation in Ethiopia: Vision, Systemic Challenges, and Prioritized Interventions Working Strategy Document, Addis Ababa, Ethiopia.

[33] Moriasi, D. N., Arnold, J. G., Van Liew, M. W., Bingner, R. L., Harmel, R. D., \& Veith, T. L..2007. Model evaluation guidelines for systematic quantification of accuracy in watershed simulations. Transactions of the ASABE, 50 (3), $885-900$.

[34] Nelson, R. L. 2005. Tassel emergence and pollen shed. Corny news network.

[35] Solomon Zewdu Altaye, Binyam Kassa, Bilatu Agza, Ferede Alemu and Gadisa Muleta. 2014. Smallholder cattle production systems in Metekel zone, Northwest Ethiopia. Research Journal of Agriculture and Environmental Management. Vol. 3 (2), pp. 151-157.

[36] United States Department of Agriculture - Natural Resources Conservation Service (USDA-NRCS). 2004. Irrigation water management (IWM) is applying water according to crop needs in an amount that can be stored in the plant root zone of the soil. [Online] Available: www.wy.nrcs.usda.gov/technical/soilmoisture/soilmoisture.htm $l$.

[37] Yibrah G, Araya B, Amsalu N. 2015. Performance of Aqua Crop Model in Predicting Tuber Yield of Potato (Solanum tuberosum L.) under Various Water Availability Conditions in Mekelle Area, Northern Ethiopia. Journal of Natural Sciences Research www.iiste.org ISSN 2224-3186 (Paper) ISSN 22250921 (Online) Vol. 5, No. 5, World Scientific News 12 (2015) 100-110. 